\title{
PERANAN SISTEM INFORMASI DALAM PENGAMBILAN KEPUTUSAN MANAJEMEN
}

\author{
Rizky Akbar Siregar \\ Prodi Sistem Informasi, Fakultas Sains Dan Teknologi, UINSU \\ rizkysrg62@gmail.com
}

\begin{abstract}
Sistem informasi masih diperlukan dalam menetapkan pilihan yang sah dengan tujuan agar mereka membutuhkan pemahaman tentang masalah dan informasi tentang pengaturan elektif. Data yang lebih tepat mendorong pilihan yang lebih baik. Kehatihatian data bergantung pada 3 hal, yaitu data harus tepat (tepat), nyaman (garis waktu) dan dapat diterapkan (signifikansi).Komponen dalam dinamika yang harus diperhatikan adalah: motivasi dibalik dinamika, ID pilihan pilihan untuk menangani masalah, estimasi elemen yang tidak dapat diketahui sebelumnya atau melewati rentang komputasi manusia dan peralatan yang digunakan untuk mengatasinya. berkomentar atau mengukur hasilnya. dari sebuah dinamika
\end{abstract}

\section{Kata Kunci:}

Sistem informasi, Keputusan, Bisnis, Organisasi,Manajemen

\section{PENDAHULUAN}

Di zaman ini, dinamika organisasi oleh pimpinan harus diidentifikasikan dengan kerentanan dari pengambilan keputusan yang diambil. Untuk mengurangi faktor ketidakpastian, diperlukan pilihan data yang tepat dan tepat tentang kondisi yang telah ada, dan mungkin, pada saat itu

Penyusunan data ini menjadi beberapa jawaban elektif masalah sebagai bahan penilaian dalam memutuskan cara yang akan dilakukan, dengan tujuan agar pilihan yang diambil benar-benar ingin memberikan keuntungan yang paling maksimal.

\section{STUDI LITERATUR}

Studi literatur yang bersumber dari beberapa informasi dari buku, makalah,journal, karya tulis, skripsi dan sebagainya yang pastinya membahas tentang Sistem Informasi Manajemen dengan konsep Peranan system informasi dalam pengambilan keputusan

\section{METODE PENELITIAN}

artikel ini sifatnya yaitu sebuah penelitian kepustakaan (library research), hingga data yang kami diambil yaitu dari sebuah kajian teks dan buku yang sangat relevan dengan pokok atau rumusan masalah yang sesuai dengan pembahasan 
artikel ini. Artikel ini disusun sebagai suatu usaha penulisa dalam mengumpulkan dan mengolah data pembahasan ini.

\section{HASIL DAN PEMBAHASAN}

Zaman sekarang sangat membutuhkan manajemn dalam melakukan aktivitas Bahkan, Memang, bahkan perkumpulan yang paling kecil sekalipun, misalnya, keluarga membutuhkan kerangka kerja administrasi tepat. Jika tidak, akan merepotkan suasana rumah tangga yang kondusif dan menguntungkan. Jelas, ini semakin bertambah signifikan terlebih banyak asosiasi kompleks dengan fungsi dan usaha masing-masing divisi berbeda.Sistem data papan atau di sisi lain SIM dalam bahasa Inggris, management information system, SIM adalah kerangka kerja pengaturan bagian dari pengendalian interior suatu bisnis yang menggabungkan pemanfaatan individu, arsip, inovasi, dan sistem oleh pembukuan eksekutif untuk menangani masalah bisnis seperti pengeluaran produk, administrasi, atau prosedur bisnis.

Sistem informasi manajemen dipisahkan oleh sistem informasi Biasanya karena SIM digunakan untuk menggambarkan sistem informasi lain yang diterapkan untuk klien kegiatan organisasi. Secara ilmiah, istilah ini umumnya digunakan untuk pengumpulan data teknik manajemen yang terkait dengan komputerisasi atau dukungan untuk dinamika manusia, misalnya jaringan yang mendukung secara keputusan seperti DDS, kerangka kerja master, dan kerangka data kepala.
Sistem Informasi Manajemen adalah perangkat metodologi bersama yang mengumpulkan dan menciptakan informasi yang dapat diandalkan, penting dan efisien yang mendukung interaksi dinamis dari suatu organisasi. Sederhananya, ini adalah kumpulan siklus di mana informasi diperoleh, dibedah, dan diperkenalkan dengan cara yang berguna untuk tujuan dinamis. Kerangka kerja ini adalah perangkat yang sangat berharga untuk mengawasi dan mengendalikan kegiatan organisasi. Motivasi mendasar di balik sistem ini adalah untuk mengontrol semua informasi yang dikumpulkan dari setiap tingkat organisasi, merangkumnya, dan menyajikannya dengan cara yang sesuai dan meningkatkan kualitas keputusan yang diambil untuk membangun manfaat dan efisiensi organisasi.

Sistem kerja ini biasanya berbasis computer(PC) termasuk lembaran excel langsung atau tahap yang lebih kompleks. Data yang dikumpulkan dan dibedah dalam sistem biasanya berasal dari internal dan eksternal.

\section{Kemajuan Sistem Informasi Manajemen}

Menjelang dimulainya komputerisasi, data computer belum memiliki program yang bekerja secara alami, melainkan hanya menjalankan perintah yang dimasukkan secara fisik ke dalam komputer. Setelah tahun berikutnya atau lebih kurang selama tahun 2000an, sistem informasi manajemen mulai dibuat sebagai sistem kerja yang dipercaya untuk induk yang organisasi 
dan cabang yang berbeda.sistem tersebut kemudian dibentuk menjadi sistem data berbasis komputer (Computer Based Sistem Data). Sampai saat ini,system informasi berjalan tergabung dan berjalan secara konsekuen.SIM sendiri memiliki struktur sebenarnya yang dibutuhkan kelancaran aktivitas sistem yang digunakan,perangkat lunak, yaitu perangkat lunak, menjadi perangkat lunak khusus sistem umum, perangkat lunak terapa numum, serta program aplikasi.Apalagi SIMnya ada di sana basis informasi dan metode pelaksanaan organisasi kerangka dewan dan Jelas, orang bekerja di semua sistem kerja tersebut

\section{Sistem Informasi Manajemen dalam Dunia Akademis}

Ide ini menggabungkan apa yang dapat dilakukan computer di sekitar sini, bagaimana individu atau orang mengukur data, dan cara terbaik membuatnya menjadi data terbuka dan modern.

Cummings menambahkan, " informasi yang akurat di tempat yang tepat pada waktu yang tepat adalah apa yang kami cari. Disiplin ini jauh lebih beraneka ragam daripada ilmu komputer pada umumnya."

Selain ilmu komputer, ada ruang studi berbeda yang mengidentifikasi system informasi manajemn, baik pada tingkat hipotetis dan praktis:
- Sistem informasi (SI): Dalam SI, ada penekanan yang lebih penting pada alat, sedangkan kerangka data dewan lebih berpusat di sekitar aktivitas bisnis.

- Teknologi Informatika (TI): TI itu seperti SI, namun berfokus pada praktik komputer.

- Informatika: Ilmu yang menggabungkan pemrograman komputer, kemajuan system informasi, dan jaringani.

- Teknik Listrik dan Teknik Komputer: Bidang-bidang ini berpusat di sekitar kemajuan peralatan dan pemrograman serta strategi pembaruan, secara individual. Sistem informasi manajemen membantu memutuskan hipotesis dan komitmen dari perubahan ini.

\section{Konsep Dasar Sistem}

Kerangka kerja merupakan perkembangan kerja dari siklus yang saling terkait, berkumpul dan bersamasama untuk melakukan suatu tindakan atau menyelesaikan suatu tujuan tertentu. Kerangka kerja terdiri dari berbagai segmen yang berkolaborasi satu sama lain, bekerja sama membentuk satu kesatuan. Segmen kerangka atau kerangka struktur dapat berupa sub kerangka atau bagian kerangka. Setiap sepotong kerangka memiliki sifat kerangka untuk melakukan kapasitas tertentu dan mempengaruhi pameran kerangka secara keseluruhan.Media kontak antara satu bagian kerangka dengan 
potongan kerangka yang berbeda biasanya disebut antarmuka. Melalui hubungan ini bisa dibayangkan aset muncul mulai dari satu bagian kerangka kerja lalu ke bagian berikutnya. hasil untuk sub kerangka akan menjadi kontribusi dari sub kerangka lainnya. Dengan interfacing satu bagian kerangka bias mengidentifikasi dengan potonganpotongan kerangka kerja yang berbeda untuk membentuk solidaritas. Suatu kerangka kerja harus memiliki satu tujuan atau sasaran. Tujuan / heading kerangka kerja secara signifikan menentukan informasi yang dibutuhkan oleh kerangka kerja dan hasil yang akan dibuat kerangka

Informasi

Data yang diberi nama I untuk digunakan dalam pengambilan keputusan adalah informasi.Menangani informasi menjadi data atau lebih tepatnya menyiapkan informasi dari struktur yang tidak berguna untuk membantu penerima manfaat dikenal sebagai system pengolahan. Nilai data diidentifikasi dengan pilihan. Nilai data digambarkan secara umum signifikan dalam kaitannya dengan suatu pilihan. data menjadi berlebihan jika tidak ada pilihan. Pilihan dapat berubah dari pilihan iteratif dasar hingga pilihan kunci jarak jauh. Informasi berfungsi untuk membangun informasi atau mengurangi kerentanan informasi pengguna. Informasi yang diteruskan ke pengguna adalah hasil pengolahan dari kontribusi informasi dan penanganan semacam pilihan. Namun, dalam pengambilan keputusan yang menyeluruh, data hanya dapat membangun kemungkinan pilihan atau mengurangi variasi alternatif.

Kualitas suatu informasi berrgantung dari 3 (tiga) hal yaitu, informasi wajib akurat, tepat waktu dan relevan. a. Akurat Informasi harus bersih dari kesalahankesalahaan dan tidak ambigu atau hoax.

Akurat juga bebarti informasi harus sesuai fakta yang ada. Informasi harus akurat karena memiliki otoritas sebagai penyampai informasi ke penerima informasi kemungkinan banyak terjadi gangguan (noise) yang dapat mengubah atau merusak informasi tersebut.

\section{B. Sesuai jadwal}

Data yang masuk ke penerima harus sesuai jadwal. Data usang saat ini tidak akan dihargai karena data adalah alasan pengambilan keputusan

\section{Relevan}

Data ini memiliki manfaat bagi pemakainya. Ketepatan informasi mulai dari satu individu kemudian ke individu berikutnya adalah unik, misalnya, informasi tentang alasan ketidakmampuan mesin pembuat untuk pembukuan organisasi kurang relevan dan akan lebih signifikan, jika dialihkan ke insinyur organisasi. 


\section{Karakteristik SIM}

a. MIS sangat tunduk pada informasi data organisasi secara umum, dan selanjutnya bergantung pada perkembangan informasi yang dipegang oleh asosiasi.

b. SIM dalam beberapa kasus tidak dapat menyelidiki masalah.

c. MIS membutuhkan pengaturan yang tepat dan panjang, sementara pada saat yang sama memeriksa perkembangan oraganisasi di masa depan.

d. SIM biasanya disusun untuk informasi yang telah terjadi atau informasi yang sedang terjadi, bukan informasi yang akan terjadi.

e. SIM juga berada di ruang ekstra data di dalam organisasi dibandingkan dengan informasi dari luar organisasi. f. SIM biasanya tidak elastis karena jenis laporan yang disampaikan sudah susah payah diatur sebelumnya.

\section{Menetapkan Keputusan Khusus}

Menetapkan keputusan yang tidak biasa adalah menetapkan pilihan tentang tugas-tugas organisasi, yang secara eksplisit dan secara mengejutkan bersifat luar biasa. Salah satu ilustrasi penyelesaian pada pilihan eksplisit: menolak dan menoleransi permintaan kesepakatan, mengurangi atau memperluas jumlah dan jenis barang atau kantor, membuat atau membawa bahan mentah yang sedang berlangsung, menyewakan atau menjual properti atau memanfaatkan kantor organisasi sendiri, menjualnya atau mempersiapkan lebih lanjut produk.
Menurut Siagian (dalam Hasan, 2002: 10) dinamika adalah cara yang tepat untuk menghadapi gagasan tentang pilihan yang dihadapkan dan diambil. Aktivitas yang ditunjukkan oleh komputasi merupakan aktivitas yang paling pas. Arahkan evaluasi dan putuskan pilihan untuk opsi lain yang berbeda sesuai minat tertentu.

Evaluasi Keputusan di SIM

- Sifat dari keputusan, konsekuensi dari keputusan yang diambil tidak menyimpang berdasarkan apa yang diantisipasi secara umum.

- Pengulangan pilihan yang dijatuhkan oleh atasan dalam pergaulan, tingkat pengulangan (beberapa kali) pilihan yang dibuat oleh atasan.

- Kuantitas pilihan dipertimbangkan sebelum menetapkan pilihan, jumlah dan pilihan apa yang dipertimbangkan sebelum menetapkan pilihan.

- Efek samping hipotetis dari suatu kesempatan, perhitungan diselesaikan pada keputusan yang akan diambil.

- Waktu yang diperlukan untuk menentukan pilihan, jangka waktu yang diperlukan untuk menentukan pilihan.

- Jumlah pilihan yang telah diambil, jumlah pilihan telah diambil oleh manajemen yang menggunakan SIM.

- Otomatisasi keadaan bersifat rutin dalam organisasi. 
- Biaya, kemungkinan biaya yang harus dikeluarkan oleh organisasi dalam interaksi pengambilan keputusan.

Langkah-langkah dalam pengambilan keputusan:

a. Menentukan tujuan

b. Merumuskan masalah

c. Menentukan kemungkinan

alternative penyelesaian masalah dengan berbagai macam pilihan

d. Melaksanakan dan memonitor keputusan

\section{Peranan SIM dalam Pengambilan Keputusan}

Pengambilan Keputusan Salah satu fungsi fundamental dalam kepimpinan, untuk lebih spesifik, manajer lebih sering waktu, perhatian, pertimbangan, dan pengkajian digunakan untuk melihat siklus pengambilan keputusan. Pengambilan Keputusan dilakukan dengan adil dan jujur dari posisi seseorang, yang akan menjadi tugas utama yang harus diselesaikan.

Kegiatan dan metode pemimpin dalam metode penyelesaian pilihan secara signifikan mempengaruhi aktivitas dan mentalitas stafnya. Pengambilan keputusan adalah konsekuensi dari pemikiran kritis, tanggapan terhadap penyelidikan adalah hukum keadaan, dan merupakan pilihan salah satu pilihan dari pilihan lain yang ada, sama seperti hasil dari perspektif tentang masalah saat ini. Pengambilan Keputusan memiliki dua kapasitas, khususnya: awal dari semua kegiatan manusia yang sadar dan terkoordinasi, baik secara mandiri maupun dalam pertemuan, baik secara kelembagaan dan organisasi, dan sesuatu yang maju (dampak atau dampak terus berlangsung lama).SIM dibentuk guna mendorong keputusan-keputusan manajemen pada area-area problema tertentu adalah decision support system (DSS). Jadi DSS =SIM dan SIM= DSS. Tetap saja DSS itu pemusatannya lebih besar pada pengambilan keputusan, sedangkan SIM pemfokusan lebih pada penyampaian informasi. Jadi sistem informasi manajemen adalah alat penyaji informasi. Informasi apa yang harus disajikan, bagaimana rupa dan kareteristik SIM itu sendiri sangat ditentukan oleh fungsi yang dipikulnya. Dalam hal ini fungsi adalah pengambilan keputusan. Untuk dapat melakukan urusan-urusan dalam cara pengambilan keputusan, maka dibutuhkan informasi-informasi yang bermutu (akurat, tepat waktu, relevan).

Pengambilan keputusan bertujuan tunggal, apabila terjadii keputusan yang dihasilkan hanya menyangkut satu masalah. Artinya, sekali diputuskan tidak akan ada berkaian dengan masalah lain, keputusan yang dihasilkan menyangkut lebih dari satu masalah akan menjadi bersifat ganda, artinya keputusan yang diambil langsung menyelesaiikan 2 masalah atau lebih,yang bersifat kontradiktif atau yang tidak kontradiktif. 


\section{Pengambilan Keputusan dalam Sistem Informasi Manajemen pada Bisnis}

Pengambilan keputusan sangat penting karena kerumitan besar di setiap organisasi bisnis. Tanpa data yang tepat, hal itu akan mengganggu siklus pengambilan keputusan. Dalam pilihan otoritatif mengasumsikan bagian penting untuk pencapaian tujuan dan bahwa setiap pilihan bergantung pada informasi yang benar. Dengan asumsi data dapat diterapkan, pilihan tidak akan tepat dan akan menghadapi kesialan dan tantangan dalam bekerja.

Mengingat hal ini, berikutnya adalah elemen kerangka data administrasi untuk setiap jenis bisnis

- Bantuan pengambilan keputusan:

sistem kerja ini membantu siklus pengambilan keputusan dalam organisasi apa pun , pilihan dibuat bergantung pada informaso penting dan informasi penting harus diambil dari sistem data administrasi.

- Membantu Koordinasi antar Departemen:

Sistem ini juga memiliki tugas mendasar dalam membangun kolaborasi yang baik antara semua orang dari satu kantor ke kantor lainnya melalui perdagangan data yang sesuai.
- Membantu Menemukan Masalah:

Disadari bahwa kerangka kerja ini memberikan data yang dapat diterapkan tentang setiap bagian tugas. Konsekuensinya, jika ada kesalahan yang dilakukan oleh pihak manajemen, Sistem Informasi Sistem Informasi Manajemen membantu dalam menemukan jawaban atas permasalahan yang terjadi.

- Membantu dalam Membandingkan Kinerja Bisnis:

Kerangka kerja ini juga menyimpan semua informasi dan data yang dicatat dalam Database-nya. Itulah alasan mengapa sangat membantu melihat korelasi pameran organisasi bisnis.Dengan bantuan kerangka kerja terkoordinasi ini, organisasi bisnis dapat menyelidiki pameran organisasi, apa pun yang mereka lakukan setahun yang lalu atau tahun-tahun sebelumnya, dan pelaksanaan bisnis apa pun tahun ini. Hal lain juga siap untuk menghitung pergantian peristiwa dan perkembangan asosiasi bisnis. 


\section{Tujuan Sistem Informasi Manajemen}

Berikut ini tujuan dari sistem informasi manajemen.

1. Menyediakan suatu informasi untuk pengambilan suatu keputusan.

2. Menyediakan suatu informasi

berguna baik didalam suatu perencanaan, pengendalian, pengevaluasian dan juga perbaikan berkelanjutan.

3. Mempergunakan suatu informasi dalam suatuperhitungan harga pokok produk,jasa dan tujuan lainnya yang diinginkan oleh manajemen. Dari Ketiga tujuan tersebut manajer dan pengguna lainnya,harus memiliki akses menuju informasi akuntansi manajemen dan juga mengetahui cara untuk dapat menggunakannya. Informasi akuntansi manajemen tersebut bisa membantu mereka dalam mengidentifikasi suatu masalah, menyelesaikan suatu masalah dan mengevaluasi kinerja.

\section{Proses Manajemen}

Proses manajemen bisa diartikan sebagai kegiatan-kegiatan antara lain sebagai berikut.

\section{Perencanaan,}

Melakukan kegiatan terinci untuk bisa mencapai suatu tujuan akhir tertentu merupakan suatu aktivitas manajemen disebut dengan perencanaan. Oleh karena itu, perencanaan memberikan suatu penetapan tujuan dan juga identifikasi metode untuk bisa mencapai tujuan tersebut.

\section{Pengendalian}

Penrencanaanya sebagian besar hanya untuk sementara waktu. Jika ada kesepakatan sudah dibuat, perencanaan harus diperlihatkan kemudian manajer dan buruh perlu mengawal pelaksanaannya untuk menjamin penataan tersebut berjalan positif.

\section{Pengambilan Keputusan}

itu menyiratkan cara menuju pemetikan pilihan di antara yang alternative berbeda. Kapasitas administratif sebagai hubungan antara pengaturan dan pengendalian dengan tujuan agar pengurus mempunyai visi, kemampuan dan teknik yang dipilih

\section{G. Manfaat Sistem Informasi Manajemen}

Ada beberapa manfaat sistem informasi manajemen. Antara lain sebagai berikut.

1. Menjamin ketersedianya kualitas dan keterampilan dalam memanfaatkan sistem informasi secara kritis. 2. Meningkatkan jalannya informasi data yang ada secara akurat dan real time bagi para pemakai, tanpa pihak ketiga atau perantara sistem informasi. 3. Mengietahuii Keperluan akann keterampilan pendukung sistiim informasi.

4. Mengembangkan proses perencanaan secara efektif dan baik. 


\section{Kategori Sistem Informasi Manajemen}

Sistem informasi manajemen adalah istrilah luas yang mengabungkan banyak sistim khsusus. Kategori utama dalam sistem ini meliputi:

\section{Executive Information System}

(EIS): Administrasi senior menggunakan EIS untuk menentukan pilihan yang mendorong seluruh organisasi. Pemimpin membutuhkan informasi dengan tingkat ketelitian yang serius dan kapasitas untuk menemukannya.

\section{Marketing Information System} (MkIS): Kelompok promosi menggunakan MkIS untuk memberikan penjelasan tentang pengamatan rutin dan terkini dari kegiatan pemasaran. Selain itu, fungsi itu sebagai informasi untuk memecah untuk mengatur kegiatan periklanan di masa depan.

\section{Business Intelligence System}

(BIS): Kegiatan yang memanfaatkan BIS biasanya untuk menyelesaikan pilihan bisnis yang bergantung pada pengungkapan, penggabungan, dan penyelidikan informasi dan data yang dikumpulkan. Kerangka kerja ini seperti EIS, namun administrator dan pemimpin tingkat yang lebih rendah menggunakannya.

\section{Customer Relationship Management} System (CRM): Kerangka kerja CRM menyimpan data asli tentang klien, termasuk transaksi sebelumnya, data kontak, dan pembukaan transaksi. Grup promosi, perawatan klien, kesepakatan, dan kemajuan bisnis sering menggunakan CRM.

\section{Sales Force Automation System} (SFA): Bagian yang tidak umum dari kerangka kerja SFA yang merobotkan sejumlah besar usaha yang dilakukan oleh kelompok penjangkauan. Ini dapat mencakup menghubungi manajer pencarian dan pembuatan kontak, dan meminta dewan pemesanan.

\section{Transaction Processing System} (TPS): Secara fundamental, TPS dapat berupa kerangka lokasi ritel (POS) seperti Mokapos, atau kerangka yang memungkinkan pengguna untuk mencari penginapan dan memasukkan pilihan kamar, misalnya jangkauan nilai, jenis dan jumlah tempat tidur.

\section{Knowledge Management System} (KMS): Klien dapat memanfaatkan informasi yang dibuat untuk melaporkan penggunaan dan menemukan kesepakatan dari waktu ke waktu.

Financial Accounting System (FAS): Kerangka kerja ini khusus untuk divisi yang diidentifikasi dengan keuangan dan pembukuan(akuntansi), misalnya, untuk menghitung kewajiban kreditur (AP) dan hutang catatan (AR). Contoh program pembukuan terbaik yang dapat Anda manfaatkan mirip dengan Accurate Online.

\section{Human Resource Management} System (HRMS): Kerangka kerja ini menyelidiki catatan pelaksanaan kinerja karyawan dan informasi keuangan. 
Supply Chain Management System (SCM): Organisasi perakit menggunakan SCM untuk mengikuti perkembangan aset, bahan, dan administrasi dari pembelian hingga pengiriman hasil akhirnya..

\section{Jenis Laporan yang Dihasilkan}

Inti pembahasan dari sistem informasi manajemen adalah untuk menyimpan data dan membuat laporan yang dapat digunakan para profesional bisnis untuk menganalisis dan membuat keputusan. Ada3 jenis laporan pada sistem ini:

\section{Dijadwalkan}

Dibuat setelah beberapa waktu, laporan ini memanfaatkan prinsipprinsip yang diberikan oleh pemohon untuk menarik dan menata informasi. Laporan terencana berusaha organisasi untuk membedah informasi dengan cara yang mutakhir (contoh: Seorang pembawa dapat melihat tingkat barang yang hilang menurut bulan), area (contoh: Distributor dapat menganalisis proyeksi pemasaran dari berbagai toko), atau korelasi yang berbeda.

Ad-hoc

Yang ditunjuk secara khusus adalah laporan yang dibuat pengguna untuk menjawab pertanyaan, misalnya, perawatan klien. Jika laporan tersebut berguna, Anda dapat mengubah laporan dadakan menjadi laporan yang dipesan.

\section{Real-time}

Laporan semacam ini memungkinkan seseorang untuk menyaring perubahan saat terjadi. Misalnya, pimpinan CS dapat menyaring peningkatan volume panggilan yang tidak terduga dan menemukan pendekatan untuk meningkatkan efisiensi atau memeriksa panggilan yang berbeda di tempat lain.

\section{KESIMPULAN}

Manajemen seringkalii diharapkan dengan berbagai macam persoalan berkaitan dengan jenis bisnis dan usaha yang dijalaninya. Persoalanpersoalan yang dihadapi oleh manajemen sangatlah bertautan. Baik masalah yang sifatnya rutintas atau yang besifat khusus. Manajer yang baik, adalah manajer yang dapat mengambil keputusan yang tepat disaat yang tepat pula. Walaupun diketahui bahwa setiap keputusan yang diambil akan berdampak besar bagi kehidupan perusahaan dan lingkungan sekitar. Tetapi hanya keputusan yang tepat yang dapat menjadikan perusahaan atau suatu entitas bisnis dapat bertahan.

Seiiring berkembangnya pesat teknologi, telah muncul adanya suatu system yangdigunakan untuk membantu manajer untuk mengambil keputusan yang tepat dan cepat, cepat diartikan sebagai cepat dalam melakukan analisis berbagai macam alternativepilihan,serta pengakhiran dari proses pemikiran tentang masalah yang dihadapi. 


\section{DAFTAR PUSTAKA}

Wahjono.2014.'Peranan Sistem Informasi dalam Pengambilan Keputusan".JurnalSistem Informasi, Vol 10, No 2 (2014)

Hariyanto, S. (1). "Sistem Informasi Manajemen". Jurnal PUBLICIANA,9(1),80-85. Retrieved from , Vol.9 No. 1 (2016)

Handoko Hani T, (1986), Manajemen edisi 2, Yogyakarta, BPFE Yogyakarta.

cpssoft.com/blog/manajemen/d finisi-sistem-informasi manajemen-fungsi-kategori dan-manfaatnya/

Jogiyanto. 2005. Sistem teknologi Informasi, Andi, Yogayakarta.

Raymond Mcleod, Jr., 1996, Sistem Informasi Manajemen, Prenhallindo, Jakarta.

Syamsi, Ibnu. 2000. Pengambilan Keputusan dan Sistem Informasi. Jakarta. Bumi Aksara.

Rochaety, Eti, dkk. 2008. Sistem Informasi Manajemen Pendidikan. Jakarta : Bumi Aksara

Subari, Tata. 2005. Sistem Informasi
Manajemen. Yogyakarta :

Penerbit Andi

Syamsi, Ibnu. 2000. Pengambilan Keputusan Sistem Informasi. Jakarta : Bumi Aksara 